\title{
Comparison of mice gut microbiota before and after fasting for a day
}

\author{
Jiwan Hong ${ }^{1} \cdot$ Hyejun Jo $^{1} \cdot$ Tatsuya Unno ${ }^{1}$ (D)

\section{절식이 마우스 장내미생물에 미치는 영향}

\author{
홍지완 ${ }^{1} \cdot$ 조혜준 ${ }^{1} \cdot$ 운노 타쯔야 ${ }^{1}$
}

Received: 8 August 2019 / Accepted: 2 October 2019 / Published Online: 31 December 2019

(C) The Korean Society for Applied Biological Chemistry 2019

\begin{abstract}
In this study, we investigated the effects of fasting on gut microbiota of mice fed normal (CTL) or high-fat diets (HF). Mice were raised for 16 weeks and fasted for a day at the end of the experiment. Fecal samples were collected one day before and after fasting, which were analyzed using MiSeq. Our results showed that the species richness and evenness were decreased in fasted HF group, whereas no difference was observed for CTL groups. Moreover, HF fed mice gut microbiota showed different microbial communities after fasting, while CTL groups did not show microbiota shifts. Differential abundance analysis showed that fasting CTL group mice increased and decreased one operational taxonomic unit (OTU) in S24_7 and one OTU in Ruminococcaceae, respectively. On the other hand, fasting HF group mice decreased 10 OTUs and increased 3 OTUs most of which were classified to Ruminococcaceae. Our results suggest that fasting mice may affect the abundance of Ruminococcaceae species and effects of fasting seem to be more obvious for HF-fed mice compared to those of mice fed CTL-diet.
\end{abstract}

Keywords Fasting - Gut microbiota - Microbial community analysis $\cdot$ MiSeq $\cdot$ Obesity

Tatsuya Unno $(\bowtie)$

E-mail: tatsu@jejunu.ac.kr

${ }^{1}$ Faculty of Biotechnology, College of Applied Life Sciences, SARI, Jeju National University, Jeju 63243, Republic of Korea

This is an Open Access article distributed under the terms of the Creative Commons Attribution Non-Commercial License (http://creativecommons. org/licenses/by-nc/3.0/) which permits unrestricted non-commercial use, distribution, and reproduction in any medium, provided the original work is properly cited.

\section{서 론}

절식(단식)은 섭취할 수 있는 모든 음료, 음식 등을 절제하는 행위를 말한다. 일정기간 동안 절식하면 몸은 식량의 공급이 정 지되었다고 판단하여 몸 안에 축적하고 있던 영양소를 소비한 다. 또한, 절식은 섭취할 수 있는 칼로리를 일정수준 이하로 줄 어든 상태로서, 이로 인해 발생하는 산화적 스트레스에 인한 세 포 손상 및 염증을 감소시키고 에너지 대사를 최적화하여 세포 보호를 강화하는 등의 적응성 세포 반응이 일어난다고 보고되 어 있다[1]. 이러한 절식방법은 크게 3가지고 나눌 수 있는데 1) 하루동안 칼로리를 섭취하지 않고, 다음 날 원하는 음식을 먹는 방법인 Alternated-day fasting과 2) 일주일에 2일을 단식 하는 방법인 modified fasting regimens 3) 식사 시간대를 조절 하는 방법인 time-restricted feeding이 있다. 이와 같은 모든 간 헐적 단식 방법들은 체중감량 효과가 있을 뿐 만 아니라[2], 림 프종의 발생률이 크게 감소될 수 있으며[3], 유방암 발생률이 높은 과체중 여성들의 산화적 스트레스와 염증유발이 감소했다 는 연구결과가 보고되어 있다[4].

장내미생물은 사람이 소화할 수 없는 영양소인 섬유소를 분 해하여 에너지원으로 사용할 수 있도록 해주며, 또한 비만과 밀 접한 연관이 있다는 것이 많은 선행 연구를 통해 규명되어 있 다[5,6]. Turnbaugh 등[6]은 장내미생물 생태가 형성되지 않은 무균상태의 쥐에게 정상적인 쥐의 장내미생물을 이식하여 2 주 간 조사한 결과에서 대사과정이 변화하여 지방이 증가하는 것 을 확인하였다[7]. 또한, 인간 장내미생물의 약 $70 \%$ 이상 존재 하는 두가지 주요 미생물인 Bacteroidetes와 Firmicutes가 차지 하는 상대적 비율이 비만의 지표로 사용될 수 있다고 보고되어 있다[6].

두꺼비, 쥐, 도마뱀 등 5 종의 서로 다른 척추동물의 절식 후 장내미생물생태의 변화를 분석한 결과, 쥐를 포함한 일부 포유 류에서 Coprobacillus 및 Ruminococcus가 감소한다는 연구결과 [8]와 절식 후 쥐의 장내 항원 부하의 감소를 통해 건강에 유 
익한 구조의 장내미생물생태를 확립할 수 있다고 보고되어 있 지만[9], 장내미생물과 절식과의 관계를 규명하기 위한 연구는 아직 많이 부족한 실정이다. 따라서 본 연구진은 해당 연구를 통해 일반사료와 고지방사료를 섭취한 쥐의 절식 후 장내미생 물생태에 어떠한 영향을 끼치는지 조사하였다.

\section{재료 및 방법}

\section{동물실험}

제주대학교 동물실험센터에서 12시간 간격으로 명암조절과 $23 \pm 2$ ${ }^{\circ} \mathrm{C}$ 의 온도 및 $50 \pm 5 \%$ 의 상대습도 조건 하에 $\mathrm{C} 57 \mathrm{BL} / 6 \mathrm{~J}$ model 의 암컷 쥐를 이용하였으며, 제주대학교 동물윤리위원회로부터 동물실험 승인을 받았다(JNU-IACUC2016-0042). 일주일간 순화 기간을 거쳐 총 16 주 동안 일반사료 실험군(Control, CTL, $\mathrm{n}=3$ )과 고지방사료 실험군(High fat diet-treated group, HF, $n=4)$ 으로 나누어 동물실험을 진행하였다. 일반사료 실험군은 일 반사료로 주로 사용되는 AIN-93G (Protein 18.8\%, Carbohydrate $63.9 \%$, Fat $17.2 \% \mathrm{kcal}$ )사료[10]와 음수를 무한급이방법으로 섭 취하였고, 고지방사료 실험군도 $\mathrm{AIN}-93 \mathrm{G}$ 기반으로 제조한 $45 \%$ 고지방 사료(Protein 19.0\%, Carbohydrate $36.2 \%$, Fat $44.8 \%$ $\mathrm{kcal})$ 와 음수를 무한급여 하였다.

\section{샘플 설명 및 MiSeq 준비}

절식 직전 분변 7 개 샘플 $(\mathrm{CTL}=3, \mathrm{HF}=4)$ 과 절식 24 시간 이후 분변 7 개 샘플 $(\mathrm{CTL}=3, \mathrm{HF}=4)$, 총 14 개의 분변샘플을 채취하여 $\mathrm{DNA}$ 추출전까지 $-20{ }^{\circ} \mathrm{C}$ 에서 보관하였다. PowerFecal DNA isolation Kit (MOBIO, Carlsbad, CA, USA)를 이용하여 각 분변샘플 약 $0.25 \mathrm{~g}$ 으로부터 $\mathrm{DNA}$ 를 추출하였고, Illumina사에 서 제공하는 Miseq library 제작 프로토콜에 따라 $16 \mathrm{~S}$ rRNA gene 의 과변부위 중 $\mathrm{V} 4$ region에 $\mathrm{KAPA} \mathrm{HiFi}$ HotStart RaedyMix PCR kit (KAPABIOSYSTEMS, Boston, MA, USA)를 사용하 여 initial denaturation $95{ }^{\circ} \mathrm{C}$ 에서 2 분, $95^{\circ} \mathrm{C}$ 에서 20 초간 denaturation, $55^{\circ} \mathrm{C}$ 에서 15 초간 annealing, $72{ }^{\circ} \mathrm{C}$ 에서 1 분간 extension을 25 cycles 반복하였고, final extension은 $72{ }^{\circ} \mathrm{C}$ 에서
5 분간 1차 $\mathrm{PCR}$ 과정이 수행되었다. $\mathrm{PCR}$ 산물은 AMPure XP (Beckman Coulter Inc., Brea, CA, USA)를 이용하여 정제과정 후, Illumina index를 부착하기 위한 2차 PCR을 진행하였다. 2 차 $\mathrm{PCR}$ 산물은 위 정제과정과 동일하게 진행한 후, Qubit fluorometer (Invitrogen Inc., Carlsbad, CA, USA)를 이용하여 $\mathrm{DNA}$ 의 농도를 측정하였다. 모든 샘플의 $\mathrm{PCR}$ 산물을 동일한 농 도로 한 개의 $1.5 \mathrm{~mL}$ 튜브에 모아 Macrogen Inc (Seoul, Korea)으로 보내졌으며 Illumina MiSeq을 통해 염기서열분석이 진행되었다.

\section{MiSeq 데이터 분석}

MiSeq을 통해 얻어진 염기서열은 MiSeq SOP [11]를 참고하여 Mothur software [12]으로 분석하였다. Paired-end assembly를 위해 make.contigs를 이용하였으며, align은 Silva database [13], Taxonomy assignment는 Greengene_13_5 [14]를 reference 로 사용하였다. Assignment 과정 이후, Chloroplast, Mitochondria, Eukaryota, 계(Kingdom) 수준에서 분류되지 않는 염기서열들을 포함하여 비-미생물로 분류되는 모든 시퀀스들을 remove.lineage 를 이용하여 제거하였으며, Chimeric 시퀀스 또한 VSEARCH [15]를 이용하여 제거하였다. Non-metric multidimensional scaling (NMDS) 및 Tree dendrogram은 Mothur의 서브루틴을 이용하여 수행되었으며, Differential abundance test는 Linear discriminant analysis Effect Size (LEfSe) [16]를 이용하여 실 시 하였다. R software (https://www.r-project.org/) 및 STAMP software [17]를 이용하여 데이터를 시각화 하였으며, 이에 사용 한 모든 시퀀스데이터는 the Short Read Archives에 등록하였 다(PRJNA549130).

\section{결과 및 고찰}

시퀀스데이터의 표준화를 위해 각 샘플에서 $10,000 \mathrm{read}$ 를 임 의적으로 sub-sampling하여 Rarefaction 그래프와 coverage plot (Coverage $<99 \%$ )을 통해 본 연구 결과에서 사용한 모든 샘플에 대한 시퀀스데이터는 각 샘플의 장내미생물생태를 설명할 수 있
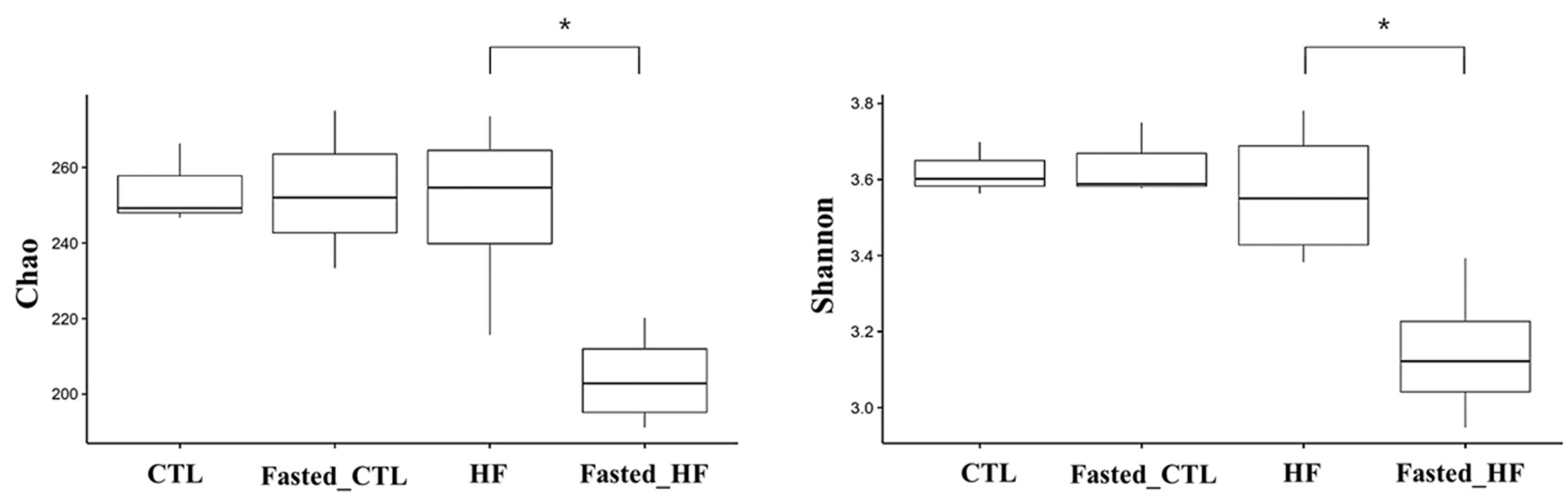

Fig. 1 Analysis of ecological indices (Richness; chao, Evenness; Shannon) with anova. In a normal diet group (CTL), there are no significant difference $(p>0.05)$ after fasting on both of chao and Shannon. However, in a high-fat diet group (HF), the chao and Shannon values are decrease significantly after fasting $(p<0.05)$ 
(A)

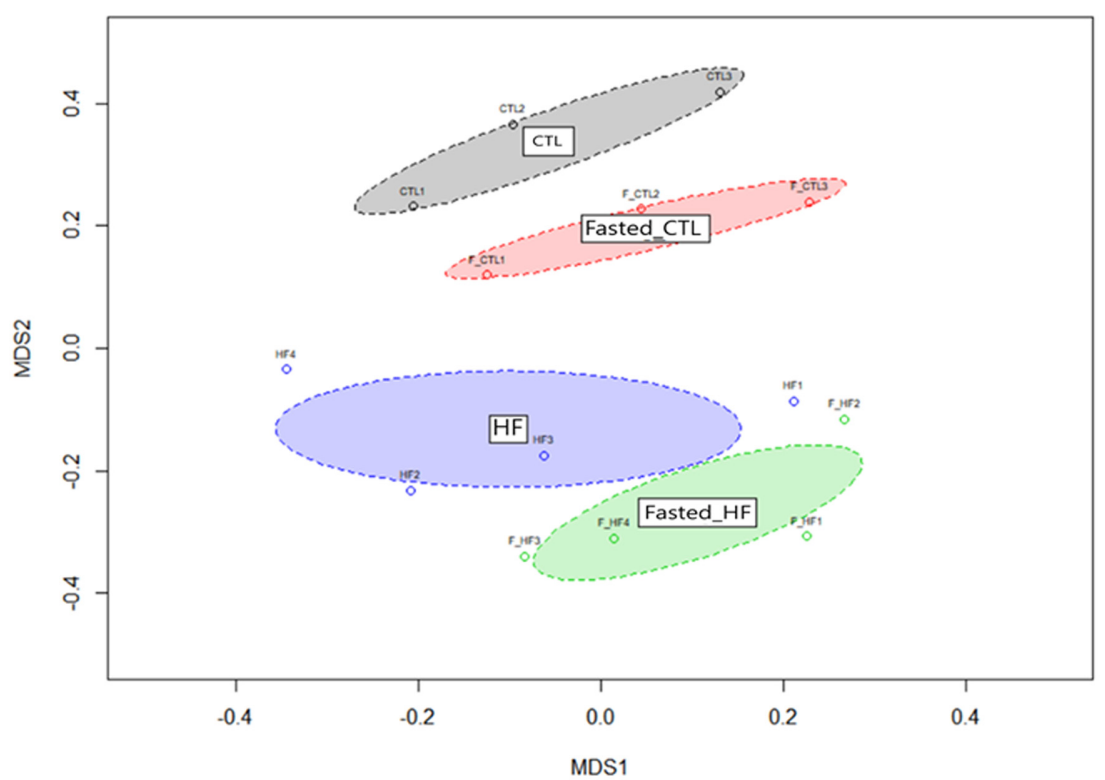

(B)

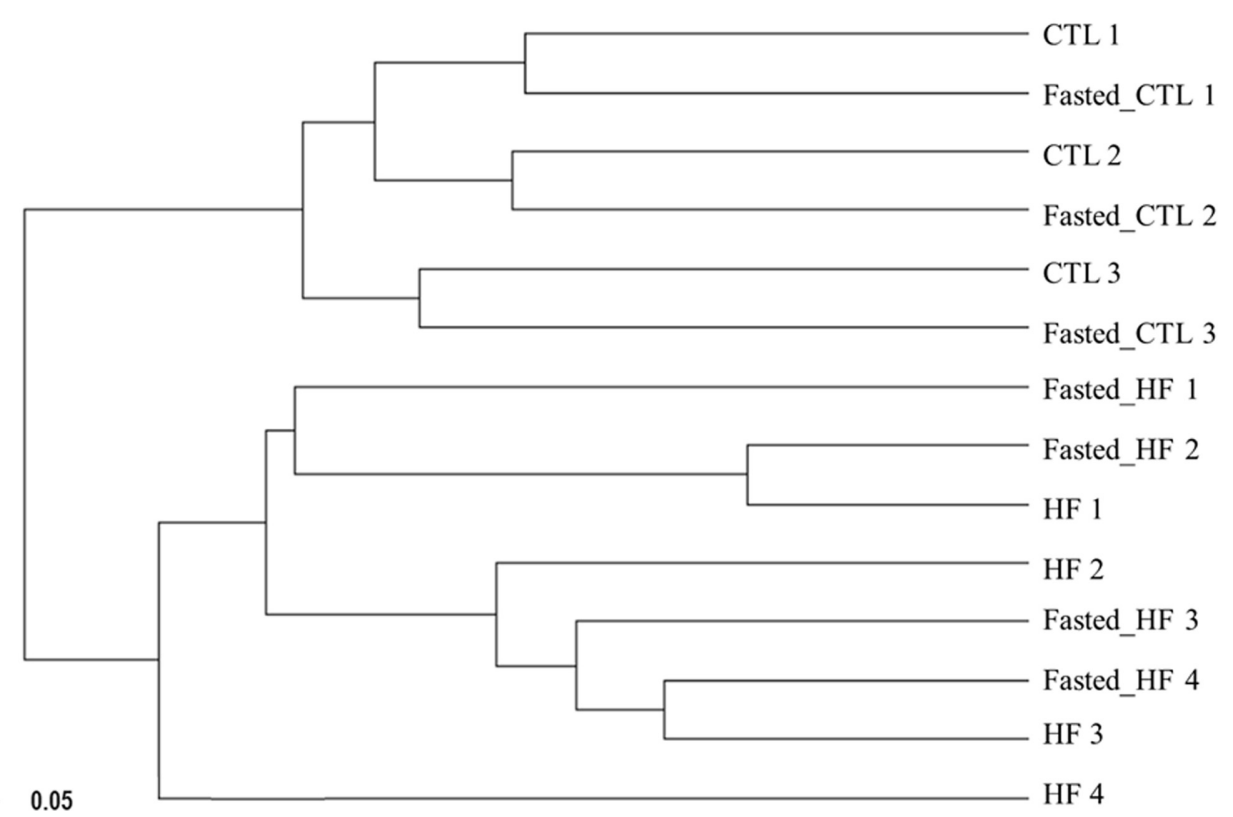

Fig. 2 Comparison of control diet and fasting, high-fat diet and fasting based microbial community with Non-metric multidimensional scaling and cluster analysis based on sample distance calculated using Bray-Curtis coefficient. (A) After fasting about all diet group, microbial community seems like shift, but no significant difference between normal diet (CTL) and fasting (Fasted_CTL), also high-fat diet (HF) and fasting (Fasted_HF) ( $p>0.05)$. (B) Cluster is separated by normal and high-fat diet, although fasting of normal diet, there is no microbial community shift. However, in high-fat diet fasting, there are microbial community shift

음을 확인하였다(Fig. S1). 장내미생물의 종 다양성(Richness)을 나타내는 Chao와 종 균등성(Evenness)을 나타내는 Shannon 지 표를 통하여 확인한 결과, 일반사료를 섭취한 그룹(CTL)의 절 식 전후의 Chao 및 Shannon 지표의 유의적인 변화가 없었으나, 고지방사료를 섭취한 그룹 $(\mathrm{HF})$ 은 절식 이후 Chao 및 Shannon 지표가 유의적으로 감소하는 것을 확인할 수 있었다 $(p<0.05)$ (Fig. 1). 그러나 두 그룹간 미생물생태 차이를 보여주는 NMDS 결과에서는 유의적인 차이가 없었으며(Fig. 2A), 고지방사료를
섭취한 그룹에서 절식 후 유의적으로 감소한 종 다양성과 균등 성이 정상범위 내의 변화로서 장내미생물생태에서는 큰 영향을 끼치지 않음을 알 수 있었다. 또한 각 샘플에 대한 장내미생물 생태간 거리 차이의 비교를 통해 나타낸 Tree 분석에서는 일반 사료를 섭취한 그룹은 절식 전후 장내미생물생태간 차이를 보 이지 않았으나, 고지방사료를 섭취한 그룹 중 마우스 HF2 및 $\mathrm{HF} 4$ 가 절식으로 인해 장내미생물생태의 변화가 발생하였음을 확인하였다(Fig. 2B). 일반사료 및 고지방사료를 섭취한 마우스 
(A)

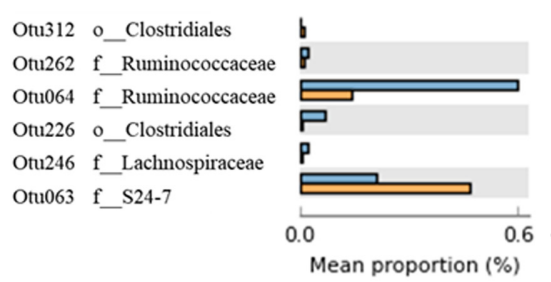

(B)

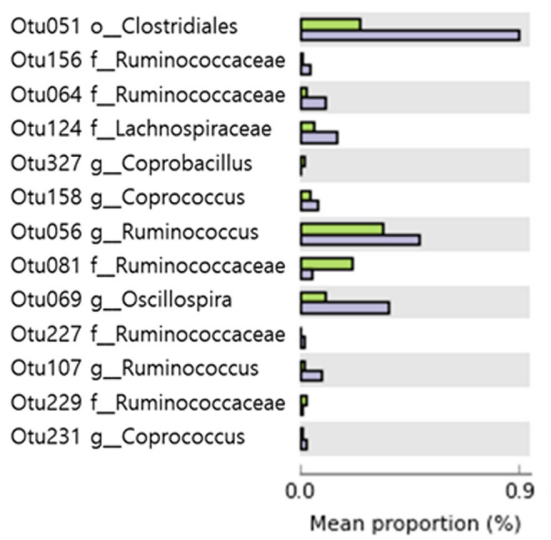

$95 \%$ confidence intervals

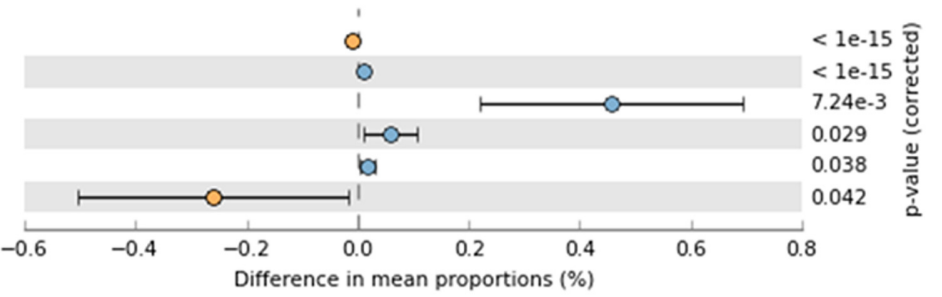

$95 \%$ confidence intervals

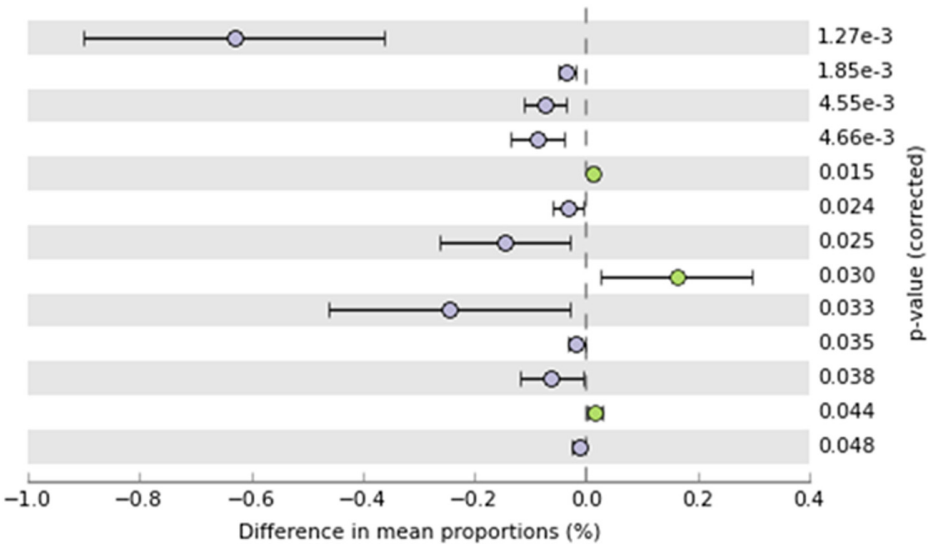

Fig. 3 Differential abundance comparison between each normal diet group, between high-fat diet group. (A) In normal diet group, 2OTUs increased and 4OTUs decreased after fasting. S24-7 is major taxonomy of classified OTUs. (B) On the other hands, high-fat diet group mice decreased 10OTUs and increased 3OTUs. And most of the OTUs were classified to Ruminococcaceae

의 분변에서 나타난 장내미생물들의 relative abundance를 OTU 및 Taxonomy 수준(Phylum, Family, Genus)으로 분석을 진행하 였다. 일반사료를 섭취한 그룹의 절식 전후의 장내미생물의 경 우 각 Phylum, Family, Genus 수준에서의 relative abundance 분석결과, Phylum 수준에서는 Bacteroidetes와 Firmicutes가 전 체 $90 \%$ 이상을 차지하는 것을 확인하여 이 두 종의 Phylum이 주를 이룸을 확인하였으며(Fig. S2A), Family 수준에서는 S237, Ruminococcaceae, Clostridiales_unclassified, Bacteroidacea가 주를 이룸을 확인하였다(Fig. S2B). 또한 일반사료를 섭취한 그 룹의 절식 전후 abundance의 차이를 확인하기 위한 LEfSe 분 석결과에서는 Phylum 수준에서 유의적인 차이는 나타나지 않 았지만, Family 및 Genus 수준에서는 Bacteroidaceae (Bacteroides) 가 절식 후 유의적으로 증가하였다 $(p<0.05)(F i g . ~ S 2 B, S 2 C)$. 고 지방사료를 섭취한 마우스의 절식 전후 장내미생물 또한 일반 사료 섭취군과 마찬가지로 Bacteroidetes와 Firmicutes가 전체 $90 \%$ 이상 차지하였고(Fig. S3A), 절식 전과 후의 Phylum 수준 에서 abundance의 유의적인 차이는 나타나지 않았다. Family 수 준에서의 abundance분석은 Bacteroidaceae와 S24-7가 전체 abundance의 30-60\%를 차지했으며, LEfSe 결과에서 해당 미생 물에 대한 절식 전과 후의 장내미생물생태 변화간 유의적인 차 이가 없었다(Fig. S3). 그러나 minor하게 존재했던 Lachnospiraceae (unclassified, coprococcus)가 고지방사료의 절식 후 유의적으로 감소하는 것으로 확인되었고(Fig. S3B), Ruminococcaceae unclassified는 절식 후 증가하는 것으로 확인되었다(Fig. S3C). STAMP software를 이용한 OTU수준에서의 Differential abundance 비교분석 결과, 일반사료를 섭취한 마우스의 경우 유의적으로 2
OTUs가 증가하는 것을 확인하였는데, 그 중 S24-7_unclassified 로 분류되는 Otu063는 가장 많이 증가하는 것으로 확인되었다 (Fig. 3A). 또한, 4 OTUs가 유의적으로 감소하는 것으로 확인 하였는데 Ruminococcaceae unclassified로 분류되는 Otu064가 가장 많이 감소하는 것으로 확인되었다(Fig. $3 \mathrm{~A}$ ). 고지방사료를 섭취한 마우스의 경우, 절식 후 일반사료에 비해 많은 수의 OTUs가 유의적인 차이를 보였으며, 3 OTUs가 증가하고 10 OTUs가 감소하는 것을 확인했다. 그 중 Clostridiales_unclassified, Oscillospira로 분류되는 Otu051, Otu069는 절식 후 가장 많이 감소하였는데, Oscillospira는 비만환자의 장내보다 건강한 사람 의 장내에서 많이 관찰되는 미생물로 알려져 있다[18-20]. 반면 에 Ruminococcaeae_unclassified로 분류되는 Otu081가 가장 많 이 증가함을 확인하였다(Fig. 3B). 일반사료 및 고지방사료를 섭 취한 그룹의 절식 전후에 Bacteroides가 Genus 수준에서 많이 나타났지만, 일반사료를 섭취한 그룹의 경우에만 절식 후 Bacteroides가 유의적으로 증가했다 $(p<0.05)$ (Fig. S2C). 그러나 고지방사료를 섭취한 그룹의 절식 전후에서는 Bacteroides가 증 가하는 양상이 보였지만 유의적인 차이는 없었다 $(p>0.05)(\mathrm{Fig}$. $\mathrm{S} 3 \mathrm{C})$. 일반사료를 섭취한 그룹에서 절식 후 증가한 Bacteroides 는 세포가 지방을 과다흡수 하는 것을 억제하는 역할을 함으로 써 체내 지방량 조절 및 비만 억제/예방 효과를 갖는 것으로 알 려져 있는 short-chain fatty acids중 하나인 propionate를 succinate pathway를 통해 생성한다고 보고되어 있으며[21], 또한 고지방 사료를 섭취한 그룹에서 절식 후 감소한 Ruminococcus는 장 건 강 유지에 중요한 역할을 하는 것으로 알려진 butyrate를 생산 하는 미생물로 알려져 있다[22]. 본 연구를 통해 일반사료 및 
고지방사료를 절식 후 유의적으로 감소한 OTUs모두 Firmicutes 에 속한 OTU로 확인하였으며, 일반사료를 절식한 마우스보다 고지방사료를 섭취한 마우스에서 절식에 의해 장내미생물생태 의 변화가 많이 일어났음을 확인할 수 있었다.

\section{초 록}

본 연구에서는 절식이 일반사료 및 고지방사료를 섭취한 마우 스의 장내미생물생태에 미치는 영향에 관하여 조사하였다. 일반 사료 및 고지방사료를 마우스에 16주 동안 무한급이 형태로 섭 취하게 하여 실험종료 직전에 1 일(24시간) 간 절식시켰으며, 절 식 전 후의 분변 샘플을 채집하고 $\mathrm{MiSeq}$ 을 이용하여 장내미생 물생태 분석을 진행하였다. 본 연구의 결과는 고지방사료를 섭 취한 마우스에서는 절식 전후 장내미생물생태 내의 종 풍부성 과 균등성이 감소한 반면, 일반사료를 섭취한 마우스에서는 차 이를 나타내지 않았다. 또한, 고지방사료를 섭취한 마우스의 장 내미생물생태에서는 절식 후 변화하는 것을 확인하였으며, 일반 사료를 섭취한 마우스의 절식 전후 변화가 없었다. Difference abundance analysis는 일반사료를 섭취한 마우스에서 절식 이후 S24-7로 분류되는 OTU는 증가하고, Ruminococcaceae로 분류 되는 OTU가 감소하는 것으로 확인되었다. 반면, 고지방사료를 섭취한 마우스에서는 절식 이후 $10 \mathrm{OTUs}$ 가 감소하고, 3OTUs가 증가하였는데, 대부분 Ruminococcaceae로 분류되는 것으로 확 인되었다. 본 연구 결과는 마우스에서의 절식이 장내미생물생태 중 Ruminococcaceae의 abundance에 영향을 미치며, 일반사료를 섭취한 마우스에 비해 고지방사료를 섭취한 마우스에서 절식에 대한 효과가 더 명확하게 나타난다는 것을 시사한다.

Keywords 미생물생태분석 · 비만 · 장내미생물 · 절식 · MiSeq

감사의 글 이 논문은 2018 년도 제주대학교 교원성과지원사업에 의하여 연 구되었음.

\section{References}

1. Longo VD, Mattson MP (2014) Fasting: molecular mechanisms and clinical applications Cell Metab 19: 181-192 doi:10.1016/j.cmet.2013. 12.008

2. Patterson RE, Sears DD (2017) Metabolic Effects of Intermittent Fasting Annu Rev Nutr 37: 371-393 doi:10.1146/annurev-nutr-071816-064634

3. Descamps O, Riondel J, Ducros V, Roussel AM (2005) Mitochondrial production of reactive oxygen species and incidence of age-associated lymphoma in OF1 mice: effect of alternate-day fasting Mech Ageing Dev 126: 1185-1191 doi:10.1016/j.mad.2005.06.007

4. Harvie MN, Pegington M, Mattson MP, Frystyk J, Dillon B, Evans G, Cuzick J, Jebb SA, Martin B, Cutler RG, Son TG, Maudsley S, Carlson OD, Egan JM, Flyvbjerg A, Howell A (2011) The effects of intermittent or continuous energy restriction on weight loss and metabolic disease risk markers: a randomized trial in young overweight women Int J Obes (Lond) 35: 714-727 doi:10.1038/ijo.2010.171

5. Ley RE, Backhed F, Turnbaugh P, Lozupone CA, Knight RD, Gordon JI (2005) Obesity alters gut microbial ecology Proc Natl Acad Sci USA 102: 11070-11075 doi:10.1073/pnas.0504978102

6. Ley RE, Turnbaugh PJ, Klein S, Gordon JI (2006) Microbial ecology: human gut microbes associated with obesity Nature 444: 1022-1023 doi: $10.1038 / 4441022 \mathrm{a}$

7. Turnbaugh PJ, Ley RE, Mahowald MA, Magrini V, Mardis ER, Gordon JI (2006) An obesity-associated gut microbiome with increased capacity for energy harvest Nature 444: 1027-1031 doi:10.1038/nature05414

8. Kohl KD, Amaya J, Passement CA, Dearing MD, McCue MD (2014) Unique and shared responses of the gut microbiota to prolonged fasting: a comparative study across five classes of vertebrate hosts FEMS Microbiol Ecol 90: 883-894 doi:10.1111/1574-6941.12442

9. Zhang C, Li S, Yang L, Huang P, Li W, Wang S, Zhao G, Zhang M, Pang X, Yan Z, Liu Y, Zhao L (2013) Structural modulation of gut microbiota in life-long calorie-restricted mice Nat Commun 4: 2163 doi: $10.1038 /$ ncomms 3163

10. Lien EL, Boyle FG, Wrenn JM, Perry RW, Thompson CA, Borzelleca JF (2001) Comparison of AIN-76A and AIN-93G diets: a 13-week study in rats Food Chem Toxicol 39: 385-392

11. Kozich JJ, Westcott SL, Baxter NT, Highlander SK, Schloss PD (2013) Development of a dual-index sequencing strategy and curation pipeline for analyzing amplicon sequence data on the MiSeq Illumina sequencing platform Appl Environ Microbiol 79: 5112-5120 doi:10.1128/ AEM.01043-13

12. Schloss PD, Westcott SL, Ryabin T, Hall JR, Hartmann M, Hollister EB, Lesniewski RA, Oakley BB, Parks DH, Robinson CJ, Sahl JW, Stres B, Thallinger GG, Van Horn DJ, Weber CF (2009) Introducing mothur: open-source, platform-independent, community-supported software for describing and comparing microbial communities Appl Environ Microbiol 75: 7537-7541 doi:10.1128/AEM.01541-09

13. Quast C, Pruesse E, Yilmaz P, Gerken J, Schweer T, Yarza P, Peplies J, Glockner FO (2013) The SILVA ribosomal RNA gene database project: improved data processing and web-based tools Nucleic Acids Res 41: D590-596 doi:10.1093/nar/gks1219

14. DeSantis TZ, Hugenholtz P, Larsen N, Rojas M, Brodie EL, Keller K, Huber T, Dalevi D, Hu P, Andersen GL (2006) Greengenes, a chimerachecked 16S rRNA gene database and workbench compatible with ARB Appl Environ Microbiol 72: 5069-5072 doi:10.1128/AEM.03006-05

15. Rognes T, Flouri T, Nichols B, Quince C, Mahe F (2016) VSEARCH: a versatile open source tool for metagenomics PeerJ 4: e2584 doi:10.7717/ peerj. 2584

16. Segata N, Izard J, Waldron L, Gevers D, Miropolsky L, Garrett WS, Huttenhower C (2011) Metagenomic biomarker discovery and explanation Genome Biol 12: R60 doi:10.1186/gb-2011-12-6-r60

17. Parks DH, Tyson GW, Hugenholtz P, Beiko RG (2014) STAMP: statistical analysis of taxonomic and functional profiles Bioinformatics 30: 3123-3124 doi:10.1093/bioinformatics/btu494

18. Beaumont M, Goodrich JK, Jackson MA, Yet I, Davenport ER, VieiraSilva S, Debelius J, Pallister T, Mangino M, Raes J, Knight R, Clark AG, Ley RE, Spector TD, Bell JT (2016) Heritable components of the human fecal microbiome are associated with visceral fat Genome Biol 17: 189 doi:10.1186/s13059-016-1052-7

19. Konikoff T, Gophna U (2016) Oscillospira: a Central, Enigmatic Component of the Human Gut Microbiota Trends Microbiol 24: 523524 doi:10.1016/j.tim.2016.02.015

20. Peters BA, Shapiro JA, Church TR, Miller G, Trinh-Shevrin C, Yuen E, Friedlander C, Hayes RB, Ahn J (2018) A taxonomic signature of obesity in a large study of American adults Sci Rep 8: 9749 doi:10.1038/ s41598-018-28126-1

21. Reichardt N, Duncan SH, Young P, Belenguer A, McWilliam Leitch C, Scott KP, Flint HJ, Louis P (2014) Phylogenetic distribution of three pathways for propionate production within the human gut microbiota ISME J 8: 1323-1335 doi:10.1038/ismej.2014.14

22. Schwiertz A, Lehmann U, Jacobasch G, Blaut M (2002) Influence of resistant starch on the SCFA production and cell counts of butyrateproducing Eubacterium spp. in the human intestine J Appl Microbiol 93: $157-162$ 